\title{
Book Review: Local Government and Decentralization in Ghana
}

\author{
Commonwealth Journal of Local Governance \\ Issue 7: November 2010 \\ http://epress.lib.uts.edu.au/ojs/index.php/cjlg
}

\author{
Keshav C. Sharma \\ University of Botswana \\ Gaborone, Botswana
}

\section{Book Review: Local Government and Decentralization in Ghana} Kwamena Ahwoi (Unimax Macmillan, Accra, Ghana, 2010, pp.282)

The author of this volume, Kwamena Ahwoi, has no doubt benefited in the writing of this book from the insights acquired as a Minister of Local Government in Ghana for over 12 years (he is presently a staff member of the Ghana Institute of Management and Public Administration). Kwamena Ahwoi was the Minister who piloted the Local Government Act 1993 and other important legislation related to local government such as the District Assemblies Common Fund Act 1993, and the National Development Planning (System) Act 1994. This book therefore is both an insider's view and an academic account.

The book is organized in four parts. It begins with a theoretical framework where the author correctly emphasizes that decentralization and devolution are closely aligned, whereby actual authority over and responsibility for resources are ceded to local governments. Effective decentralization does not occur without devolution. Delegation, de-concentration and privatization do not result in effective decentralization. In the second part a history of local government in Ghana and decentralization efforts undertaken since independence is presented. The third part explains the operation of local government as provided in the 1992 constitution, and in the final section, the author discusses how some of the mistakes - past and present - could be tackled to strengthen local government and decentralization today. 
Thus, the book covers several crucial aspects of local government and decentralization in Ghana. This includes detailed accounts of the present structure of local government at different levels such as administrative decentralization, decentralized planning, and fiscal decentralization. Ahwoi highlights major problems confronted by local government in Ghana, discusses the prospects for decentralization and puts forward his proposals for reform.

The problems confronted in the process of decentralization and strengthening local government are familiar and confront all African countries. For instance, at the beginning of his concluding chapter he writes that "many of the problems that confront local government and decentralization efforts in Africa generally have fortunately been overcome in Ghana's programme for local government reform and decentralization implementation” (p. 241). He continues: "Nevertheless, they bear recapping because they could easily recur and because some of them linger on in the form of problems or near problems occasioned by the reform programme” (p. 241). Notwithstanding this conclusion, the following problems in Ghana deserve serious attention for the potentially worthwhile lessons for other African countries engaged in strengthening decentralization and local government.

1. Vague Local Government Laws: Laws on local government and decentralization have often been criticized as being vague, unclear and uncertain. The organizational structures are diffused and the role relationships and lines of authority are ill defined. Consequently, officials lack sufficient understanding of local government reforms and of the roles expected of councillors and the district bureaucrats.

2. Insufficient Preparatory Groundwork for Reforms: Central government reformers often do not correctly assess the functional capacity of local authorities to which functions are to be transferred. Local authorities may not be ready or capable to manage such functions, or the functions are transferred to the local authority but they are performed or managed ineffectively. Furthermore, stakeholders are often not involved in the design and structure of the reforms. As a result, when they are introduced such reforms look alien or appear as foreign impositions, which makes their acceptability and implementation difficult. Worse, there is often inadequate or no training to prepare stakeholders for the reforms. 
3. Large-scale transfer of functions: Often there is a single transfer of large-scale responsibilities and powers to unprepared decentralized units. The potential for improving outcomes with transfer of functions would increase if they are transferred incrementally, according to capacity, or by selective decentralization in different stages or areas. Issues of costs, benefits and local context should also be considered.

4. Lack of Trained and Experienced Personnel: Local governments are unable to attract skilled manpower because of a poor image, difficulties associated with training the human resource pool, and inadequate training facilities.

5. Inadequate Financial Resources: In Ghana, local government does not receive an adequate share of national resources. Central government controls the lion's share leaving local government with a minimal amount. Elastic and easily paid taxes such as customs duties, excise duties, income tax and value-added tax are appropriated by the central government. This leaves the more difficult 'inelastic' and regressive taxes for local governments to collect such as property rates, basic rates (poll tax), and market rolls. This tendency results in over-dependence of local government on central government grants, which further strengthens the central government's stranglehold control over local affairs.

6. Corruption and other Financial Malpractice: Corruption at both central and local government levels is a major concern in Africa. Incidences of corruption in local government arise when more resources are released to local governments than there are functions to perform or undertake. In such situations, excess resources are simply dissipated through corruption and other financial malpractice. Another result of mismatched allocations of functions to local government is inefficiency when there are not enough resources to perform functions. Annual reports of the Auditor General on the accounts of District Assemblies are replete with numerous instances of financial malpractice and corruption, such as payments in millions to companies for contracted work not completed, overpayments, payments without records, embezzlement, misappropriation, irregular procurements, tax irregularities and violations of financial rules, regulations and instructions. 
7. Bureaucratic Obscurantism: African countries are faced with the problem of a lack of bureaucratic will to decentralize. African central bureaucrats have a paternalistic, centralist orientation and are thus reluctant to cede their power.

8. Apathy: Citizens do not take much interest in the work of local governments; many do not even know what they do. Local government election statistics reveal a much lower voter turn-out compared to central government elections.

9. 1

Having observed, however, that many problems related to development of local government and decentralization have been resolved in Ghana - or are in the process of being resolved Ahwoi's view is that the prospects of local government in Ghana are "very bright indeed" (p. 251). He identifies a number of proposals for further reform that in his view could help in meeting some outstanding challenges in Ghana. Some of these are highlighted:

- Central government must be committed to decentralized planning systems so that the programmes and projects of District Assemblies are truly reflected in national development plans.

- The constitutional ban on chiefs taking part in active party politics must be reviewed.

- Sanctions must be applied to those who breach the law on the non-partisanship of District Assembly elections because those are breaches of the constitution.

- Issues of district boundaries demarcation, the configuration of districts, the naming of districts, and the selection of district capitals should be addressed in consultation with and through the active involvement of chiefs, opinion leaders and those people affected by such changes.

- A future revision of the Local Government Service Act should properly define the roles and relationships between the Ministry of Local Government, the Local Government Service (appointed officials) and the Local Government Service Council.

\footnotetext{
1 The election statistics for local government elections in 1994, 1998, 2002 and 2006 were 29.3\%, 41.6\%, 33.1\% and $42.6 \%$ respectively. The comparative turnout figures for the Presidential elections for the same years was 50.2\% (1992), 77.9\% (1996), 61.7\% (2000), $60.4 \%$ (2000) and $85.1 \%$ (2004).
} 
Some of the material on organizational arrangements and statutory provisions devised in Ghana for promoting decentralization and strengthening local government may be of value as lessons for other countries. One such organizational innovation is the District Assemblies' Common Fund established by the Constitution of Ghana as an instrument for promoting fiscal decentralization - an essential prerequisite for strengthening the meaningful autonomy of local government.

Article 252 of the constitution of Ghana provides that the Parliament has to allocate not less than $5 \%$ of the total revenue of Ghana among District Assemblies, to be distributed in quarterly installments. This is done on the basis of a formula to be approved by Parliament and to be administered by a District Assemblies' Common Fund Administrator. The formula for the distribution of the Common Fund, as developed by the Administrator over the years, uses five main factors as inputs:

- Equality: Every Assembly irrespective of size or population is allocated a fair amount of the Fund;

- Population Density: The greater the population density of a district the more of the Fund the Assembly receives.

- Service Pressure: The greater the population of a district the more of the Fund the Assembly receives, reflecting the greater absolute demands on services provided by the Assembly.

- Development Status: The more developed a district, the less of the Fund the Assembly receives. The development status of the district is measured by the number of schools, the ratio of teachers to pupils per class, the number of health facilities and ratio of doctors per head of population, the availability of electricity, telecommunications and postal services, and the presence of banking and other financial institutions.

- Incentive: An increase in locally mobilized revenues in real terms relative to a given base-year results in an increased allocation, whilst no increase or a decrease results in a zero percent allocation. 
Once developed, the Common Fund Formula is submitted to Cabinet by the Minister of Local Government and subsequently to Parliament for approval. ${ }^{2}$ Once approved and passed on the floor of the House by resolution, the Minister of Local Government then formulates guidelines on the categories of projects on which the Fund must be expended.

These practices adopted in Ghana promote decentralization in so far as the District Assemblies receive a certain percentage of central revenue as a right. However, the authority vested in the Minister of Local Government for the formulation of Guidelines for the utilization of Funds is a significant provision that strengthens central authority and maintains centralization. Between 1999 and 2007, as much as between 41\% and 50\% of the Common Fund was transferred as 'tied grants' determined by the Minister of Local Government. Also, the Parliament has allocated 6\% of the Fund for use by Members of Parliament as an 'MP's Constituency Development Fund' and retains 4\% of the Fund for central government agencies. This instrument for fiscal decentralization therefore does not strengthen the autonomy of local government in reality as much as the constitutional provision suggests.

Some of Ahwoi's other observations in the book should also be highlighted as these reflect the insight of an ex-Minister of Local Government. Ahwoi is indeed correct when he emphasizes that decentralization is a political process which seeks to promote more realistic programmes, better coordination and participatory democracy. He also recognizes the need for a strong central government for promoting decentralization, and is of the view that local resource utilization in unitary states works best when there is strong centre to coordinate the local governments. Further, he emphasizes that decentralized governance requires a strong national civil service and strong local government administration(s).

This book is a worthwhile addition to the existing academic literature on decentralization and local government in Africa. Although it deals exclusively with Ghana, it is of relevance to students, scholars and practitioners outside that country.

\footnotetext{
2 The convention that has developed in Ghana's parliament is for the formula to be considered by a
} Parliamentary Committee and, upon agreement, passed on the floor of the House by resolution. 